Kucserka, Zsófia. "Parent-Child Resemblance in Literature Before the Age of Genetics: A Physiognomic Interpretation of the Novels of Zsigmond Kemény and Miklós Jósika." Hungarian Cultural Studies. e-Journal of the American Hungarian Educators Association, Volume 14 (2021): http://ahea.pitt.edu DOI: 10.5195/ahea.2021.416

\title{
Parent-Child Resemblance in Literature Before the Age of Genetics: A Physiognomic Interpretation of the Novels of Zsigmond Kemény and Miklós Jósika
}

\section{Zsófia Kucserka}

Abstract: Although Zsigmond Kemény (1814-1875) and Miklós Jósika (1794-1865) inevitably figure among the most significant writers of nineteenth-century Hungarian literature, the interpretation of their novels is embedded within international historical contexts that are often inaccessible to the present-day reader. This study examines the physiognomic meanings of parent-child similarity in nineteenth-century novels and thus situates the examined works within the context of European literary and intellectual history. Such an interpretation of the novels reveals the diverse and strong current in the history of European ideas with which the analyzed texts engage in a lively dialogue.

Keywords: physiognomy, nineteenth-century Hungarian novel, heredity and characters in literature, Zsigmond Kemény, Miklós Jósika, interpretation in historical context

Biography: Zsófia Kucserka currently works at the Institute for Hungarian Literary Studies, University of Pécs (Hungary) as an Assistant Professor, where she teaches nineteenth-century Hungarian literature. Her PhD dissertation (published in 2017) examined the historical-anthropological aspects of characters in the nineteenthcentury novel. She has published studies on nineteenth-century Hungarian female writers and their ego-documents.

(kucserkazsofi@gmail.com)

While the resemblance between children and their parents has been a universal observation of humankind for several millennia, the actual interpretation of such similarity occurs within culturally determined and, as such, diverse theoretical frameworks the changing concepts of which are consistently reflected in literary works from different times. The laws or regularities of heredity in pre-genetics medical theories followed mysterious patterns. In most cases, children were thought to carry a combination of their parents' facial features and often revealed traits from grandparents or previous generations - but this is by no means a universal rule. Diseases and characteristic features are sometimes inherited over generations, sometimes not. It is no coincidence that the first descriptions using the word "genetics" are embedded in the context of animal husbandry and crop farming since the regularities of heredity which facilitated the breeding of healthy, strong offspring became known and used much earlier in relation with animals (Festetics 1822; Mendel 1865). The question of human heredity and resemblance, however, seemed a more complex and more inscrutable issue. According to Aristotelian anthropology, which defined the theory and practice of European medicine for centuries through 
Kucserka, Zsófia. "Parent-Child Resemblance in Literature Before the Age of Genetics: A Physiognomic Interpretation of the Novels of Zsigmond Kemény and Miklós Jósika." Hungarian Cultural Studies. e-Journal of the American Hungarian Educators Association, Volume 14 (2021): http://ahea.pitt.edu DOI: 10.5195/ahea.2021.416

Galenic and Avicennan medicine, the body and soul operate in an inseparable unity within which the powers of the soul are capable of causing bodily changes (Aristoteles 1999; Wright and Potter 2000). According to the physiognomic thinking associated with the Pseudo-Aristotelian tradition, the child's resemblance to their parents is predominantly determined by the strong imagination of the mother while the parents' creative imagination impresses itself upon the born child through the power of the soul (Akasoy 2008: 119-141, in particular: 132). By taking a detailed look at two nineteenth-century Hungarian authors, I argue that in novels written before the age of genetics, a familiarity with earlier, now obsolete theories of resemblance is indispensable for the interpretation of character behavior and sheds new light on the reading of these works (on the physiognomic context of literature see Tóth 2019). The most influential of these theories during the nineteenth century was Lavaterian physiognomical thinking, an interpretative framework that came to define everyday social interaction (Percival 2003; Pearl 2010) to such an extent that a physiognomical interpretation and an explanation of the relevant parts of the plot was uncalled for in novels (Tytler 1982). The most famous example of this organic link between physiognomic thinking and the literary representation of heredity is Johann Wolfgang von Goethe's novel, Elective Attractions (1809), in which the child does not resemble the parents. Goethe's hugely successful work was a natural benchmark for nineteenth-century Hungarian novels as well. Therefore, as I will argue based on an analysis of works by Zsigmond Kemény and Miklós Jósika, familiarity with contemporary physiognomic theories, especially Lavater's ideas, and influential earlier literary representations of physiognomic thinking is indispensable for a proper understanding of nineteenth-century Hungarian novels.

My first example of this organic connection is Zsigmond Kemény's short story, Ködképek a kedély láthatárán ['Apparitions on the Mind's Horizon'] (1852-53), in which two different storylines are intertwined. In the fatal marital story of Ameline (Cecil) and Florestán, the happy home life of the protagonists is ruined by an ill-fated frivolous move and its terrible consequences. The aristocratically proud Count Villemont Florestán, who allows himself small adventures even though he loves his wife, arranges a rendezvous with his wife's maid, Ágnes, in the red room, a remote, abandoned part of the castle, yet sends his Moor footman, Jágó, to the secret meeting in his stead. Meanwhile, tormented by guilt, Ágnes confesses to her mistress that she is supposed to have a secret, illicit meeting with Florestán. On a whim, Ameline goes to the red room at the agreed time and, instead of her husband, unwittingly meets the servant Jágó. Their ensuing, naively sinful adultery results in the birth of a "deformed" child who is relentlessly hated by Florestán, but loved by Ameline. The birth of the "half-breed" child, who constantly reminds the characters of the notorious events in the red room, splits the spouses. When the illegitimate son falls sick and later dies, Florestán wants to return to his offended wife without success, since Ameline is disgusted by the way he insulted her in her maternal affection and leaves her husband forever.

The narrative poses several challenges for a present-day interpreter and was already problematic for literary historians Jenő Péterfy (Péterfy 1983: 581) and Ferenc Papp (Papp 1923: II.160-162), who both felt that it was atypical of Kemény's oeuvre mainly because the slightly overcomplicated story relies upon earlier literary patterns and French romantic clichés that try to impress readers not with an elaborate psychological grounding so much as with exciting twists of the plot. The story is grotesque and melodramatic while the setting of the romantic castle hidden among the wild cliffs and containing a mysterious red room also seems exaggerated. Through the plot's bizarre sexuality, the emphatic eroticism of the story of the red room may also have garnered the reproach of critics who preferred a slow, balanced, analytical type of prose. In 
Kucserka, Zsófia. "Parent-Child Resemblance in Literature Before the Age of Genetics: A Physiognomic Interpretation of the Novels of Zsigmond Kemény and Miklós Jósika." Hungarian Cultural Studies. e-Journal of the American Hungarian Educators Association, Volume 14 (2021): http://ahea.pitt.edu DOI: 10.5195/ahea.2021.416

addition to the story's melodramatic exaggerations, the motives and psychological dynamics of its characters are also difficult to interpret. The latter is true at the level of the plot as well because the conflict between Florestán and Ameline is precisely situated in the fact that they do not understand one another's motives, thereby leading to questions that also challenge the reader. It is incomprehensible for Florestán that Ameline should cling to her "freak" child, who, moreover, always reminds him of her sin. Ameline similarly does not understand why her husband remains insensitive and cannot understand that he is still her child, notwithstanding the exact parentage or the circumstances of the child's conception. Their conflict reveals a clash between different concepts surrounding motherhood and progeny. Florestán upholds a dynastic, patrilineal family model within which an illegitimate child is by no means a part of the family; in Ameline's view, motherhood is a much more direct, physical relationship marked not by family name, but rather by a physical affection. Her attitude is indicated by her insistence upon breastfeeding and nurturing the child herself (on new family models of the age see Sabean and Johnson 2011; regarding the changes of motherhood see Badinter 1981).

Beyond the moral or ideological concerns Ködképek may have caused for contemporary readers, modern readers will also experience difficulties in understanding. It is a challenge to comprehend Florestán's unfair behavior toward Ameline, for example, when he was the one who was unfaithful in the first place. Yet the short story consistently characterizes Florestán as a noble person who loves his wife yet is somewhat prone to wantonness and leaves Florestán's obsessive hatred for Ameline's illegitimate child and (later) Ameline herself completely unexplained. Initially, it might be assumed that the child bears the marks of the violent or unnatural conditions of his conception and therefore appears "deformed." However, a close reading of the text suggests that the child's distorted features are exclusively rooted in his interracial origins. All we learn from the descriptions of the narrative is that the boy has kondor fekete haja van ['hair as black as a vulture's wing'], a flat nose and brown skin. In other words, the sentiment of disgust and horror in Florestán is simply caused by the fact that the child is not blond-haired and white-skinned. Although not necessarily familiar to modern readers, even nineteenth-century anthropological views should not warrant such a violent response to Otherness and horror. This case is an example of when a consideration of the physiognomic context might help us. According to Sander Gilman's analysis of the cultural imagination of the period, from the end of the eighteenth century, sexual intercourse between black and white people became a symbol of extreme desire and deviant sexuality (Gilman 1985: 81-93 and 109127). Thus, the exoticism of black-skinned characters could in some literary works be interpreted as particularly beautiful and attractive during the nineteenth century. Kemény's oeuvre provides an example of this form of exoticism in the short story, Poharazás alatt ['The Drinking Party']. In this work, the character, Dr. Taddé, experiences strong affection for the beautiful Mataba, a "red-skinned," exotic Indian woman and the charming wife of the eldest son of an Indian chief.

To provide additional context for this cultural phenomenon, similar tendencies can be found in Miklós Jósika's novel, A könnyelmüek ['The Libertines'] (1837). A work that can be regarded as a direct antecedent of Ködképek, Jósika's text presents a very different case from that of Florestan and Ameline's: in A könnyelmüek, the beautiful black woman, Ázála's irresistible attractiveness triggers all the plot twists. During his travels in America, the protagonist of the novel, the Transylvanian Iván Serédi falls in love with Ázála, wife of the former slave, Motabu. Originally a slave, Motabu bought Ázála her freedom when she was a little girl and provided her with a good education in order to have a faithful wife for himself. Favored by women according to the narrative, Serédi tries to elope with Ázála to Europe, where they can live happily together 
Kucserka, Zsófia. "Parent-Child Resemblance in Literature Before the Age of Genetics: A Physiognomic Interpretation of the Novels of Zsigmond Kemény and Miklós Jósika." Hungarian Cultural Studies. e-Journal of the American Hungarian Educators Association, Volume 14 (2021): http://ahea.pitt.edu DOI: 10.5195/ahea.2021.416

in freedom. Serédi's plan fails when Motabu discovers his wife's infidelity and kills her in a jealous rage. The second half of the novel details Motabu's later revenge upon Serédi. Under a pseudonym, Motabu enters Serédi's service and wins his new "master's" trust. Years in the making, Motabu enacts his revenge when Serédi falls in love again and marries the charming Idali. During Seredi and Idali's honeymoon, Motabu locks Serédi into the cellar, dons Serédi's nightshirt and sneaks into the bedroom of Idali, who is expecting her husband back from a wolf hunt. After sprinkling Serédi's cologne on himself, Motabu sneaks into Idali's completely dark room. Idali believes that the man in her room is her husband, returned from the wolf hunt, until an hour later, when Motabu opens the window wide before leaving. Aided by the moonlight, only then does Idali recognize the Moorish slave, and she screams in horror. It is clear from the text that Idali thought she had been with her own husband.

As happened in Ködképek, a mulatto child, George, is born from the adultery. Although Idali and Serédi will never recover from the ominous event, they will later have a beautiful, blonde-haired girl and eventually find some peace. In this framed narrative, the story of Ázála, Motabu, Serédi and Idali is transmitted through the memoir of the interracial son conceived out of Motabu's revenge. George gives his memoir to his friend, Árkosi, who later marries Ida Serédi, the grown-up daughter of legitimate origins. Thus, by the end of the novel, the conflict that roiled relations among the first generation is reconciled by the second generation.

In these two works by Kemény and Jósika, the core of the sujet - a black man's sexual relations with a white woman, swapped roles, a mistaken sexual encounter, sinless adultery, an interracial child born of an illicit sexual union/encounter - is the same, yet the two authors treat the anecdote in significantly different ways. The text of Ködképek remains silent about the events in the red room. We do not know if Ameline mistook Jágó for Florestán in the dark, whether she embraced her husband in spirit, or if violence occurred in the red room. Maybe she recognized the intruder, but their encounter was not violent? The reader has no way of knowing the answer to this question. Jósika, on the other hand, leaves no doubt in his reader as to what happened between Motabu and Idali.

More tellingly, in the description of the event's aftermath, the narrator carefully explains to his reader the different characters' state of mind, along with the reasons:

In his soul, Serédi was convinced of Idali's innocence; he knew that she was a victim of his frivolity; he knew all this, and yet the deluge of temper, like waves splashing into the rock, pulled him back and forth to his wife; that hour, that dreadful hour! It stood as a dark wall between him and Idali....

[Lelkében meg volt Serédi gyözödve Idali ártatlanságáról, tudta, hogy az könnyelmüségének áldozatja; mindezt tudta, s mégis az indulatok árja, mint a sziklába csapkodó hullámtörés rántá őt el, s újra vissza nejéhez; azon óra, azon iszonyú óra! sötét elválasztó falként állott közte s Idali között].... (Jósika 1911: 180; All quotations translated into English by Csaba Maczelka)

In A könnyelmüek, Serédi is fully convinced of his wife's innocence: the same is not true of Ködképek, in which Ameline's maternal feelings arouse Florestán's suspicions regarding what happened in the red room: 
Kucserka, Zsófia. "Parent-Child Resemblance in Literature Before the Age of Genetics: A Physiognomic Interpretation of the Novels of Zsigmond Kemény and Miklós Jósika." Hungarian Cultural Studies. e-Journal of the American Hungarian Educators Association, Volume 14 (2021): http://ahea.pitt.edu DOI: 10.5195/ahea.2021.416

Ameline, how can I ever put myself in that wonderful, that sickly mood that is yours? You behave like an enemy to your good name and our family, you are raising a snake, which will always hiss our mistakes with its poisonous tongue. You want to show the sin, from which your feelings are at least pure, to the world, so that no one can doubt its existence. You kiss shame with love....

[Ameline, ugyan hogyan tehessem be valaha magamat azon csodálatos, azon beteges hangulatba, mely a tiéd? Te mintha ellensége lennél jó nevednek és családunknak, kebleden melengeted a kígyót, mely mérges nyelvével mindig tévedéseinket fogja sziszegni. Te a bünt, melytöl legalább érzéseid tiszták, a világnak felmutatni akarod, hogy létezése felöl senki sem kételkedjék. Te szeretettel csókolod meg a gyalázatot....] (Kemény 1996: 287)

At the end of the same debate, Florestán states the following stance regarding motherhood: "Motherhood, my dear, needs the right of the altar and the duty of the oath, or at least unfaithful love, sinful attraction and frivolity. Either it needs virtue, or at least a knowledge of sin. Under which pretense do you call yourself a mother?" [Az anyaságra, kedvesem, vagy az oltár joga és az eskü kötelessége kell, vagy legalább a hütlen szerelem, a vétkes vonzódás és a könnyelmüség. Vagy erény kell rá, vagy legalább tudalma a bünnek. Melyik cím alatt állítod magad anyának?] (Kemény 1996: 289) The similarity between the two works' core plots comes as no surprise since Kemény's oeuvre is characterized by a literary competition with Jósika, obviously an important source of inspiration for Kemény since he frequently adapted subjects and stories from Jósika. Their poetic competition is a well-established fact in critical literature (most recently in Laczkó 2019). In the case of $A$ könnyelmüek and Ködképek, Kemény not only borrows the core of the plot, but also adopts the method of narration to some extent, along with the complex narrative structure. Both texts place the retrospective storytelling into a framed structure: George's memoirs are read through in the novel by Árkosi, while in Kemény's work we listen to the story of Ameline via her pseudonym of Cecil, who delivers an oral narrative to the character of Várhelyi. In both novels the narrators (George and Cecil) narrate the fatal events of their own lives (in written memoir, or as oral narrative). The personal involvement of the two diegetic recipients is identical as well: Árkosi learns about his future bride's family history, while Várhelyi is an obviously affected recipient of Cecil/Ameline's life story, since he is attracted to the narrator. Furthermore, a letter written by Kemény to Miklós Jósika reveals that Kemény not only appreciated Jósika's widely acclaimed, historical fiction, but also his contemporary novels that discussed subjects related to private life (Kemény 2007: 43). It is therefore particularly interesting to see which elements of the story and the narrative are substantially different in Kemény's rendering. As regards the psychological justification of the protagonist's behavior, the main difference in Kemény's work is that Florestán feels no guilt and instead becomes seriously hostile toward his wife and her illegitimate child. Instead of blaming her husband for her situation, Ameline meanwhile tries to please her husband in every possible way, at least until their divorce.

To return to the question of how lineage is portrayed in nineteenth-century prose, Ameline's child takes after the Moor footman, Jágó, whose name and skin color naturally evokes the story of Othello, one of the most popular, most frequently staged Shakespeare play in nineteenth-century Hungarian theatre. Due to its popularity, the story was common knowledge in the period, and the name of Iago/Jágó inevitably evoked the play in contemporary readers' mind (regarding the cult of Shakespeare in Hungary at the time see Dávidházi 1998). The intertextual allusion to Othello not only introduces the theme of jealousy and perceived infidelity into the 
Kucserka, Zsófia. "Parent-Child Resemblance in Literature Before the Age of Genetics: A Physiognomic Interpretation of the Novels of Zsigmond Kemény and Miklós Jósika." Hungarian Cultural Studies. e-Journal of the American Hungarian Educators Association, Volume 14 (2021): http://ahea.pitt.edu DOI: 10.5195/ahea.2021.416

nineteenth-century narrative, but also makes affection and even love among people of different races imaginable. The inverse, combined signs of several elements of William Shakespeare's play resurface in Kemény's narrative: a black male and a white woman, fidelity versus infidelity, adultery, jealousy, etc. In itself, the name of Iago brings the subject of jealousy and attraction between people of different color to mind.

For the present-day reader, the reason for the similarity between the child conceived in the red room and Jágó is seemingly obvious: since Jágó is the biological father, the child inherited Jágó's physiognomy, skin color and racial features. However, the physiognomic relationship between inheritance and resemblance, or inheritance and imagination is not as clear in the era. The similarity of the child to his parents should be interpreted in a significantly more complex context, as in contemporary thinking resemblance can result not only from a direct physical encounter, but also from the imagination of the parents. The widely known canonical literary text of this theme is Goethe's aforementioned novel, Elective Attractions, in which Eduard and Charlottë's child is not similar to the biological parents, but instead resembles Ottilie and the Major, whom the parents were thinking of while they were making love.

[S] he pointed down to the child.

Edward looked at it and was amazed. 'Great God!' he cried, 'If I had cause to doubt my wife and my friend, this face would witness fearfully against them. Is not this the very image of the Major? I never saw such a likeness.'

'Indeed!' replied Ottilie; 'all the world says it is like me.'

'Is it possible?' Edward answered; and at this moment the child opened its eyes two large, black, piercing eyes, deep and full of love; already the little face was full of intelligence.... 'It is you,' he cried; 'the eyes are yours!... why should I not speak out the words to you? This child is the offspring of a double adultery.... Let these fair eyes say to yours that in the arms of another I belonged to you. (Goethe 1900: 329-330; For a detailed physiognomic analysis of the relevant passage see Tytler 1982: 245-246)

From a present-day perspective, the resemblance of the child born in Elective Attractions to the Major and Ottilie may seem a somewhat esoteric thought, or at the very least a powerful poetic device, as our current concept of heredity is hardly reconcilable with the idea that the desirous imagination could determine the features of a fetus instead of genes. Ameline and Idali's children are born with dark skin: there is nothing surprising about that, since we know that the father is black. The Goethe passage has a peculiar and challenging meaning that demands further explanation. For our present-day mindset, the existence of a love surpassing the laws of nature can (at best) be conceived as a means of poetic justice. However, if the above novels are read not through the lens of our current knowledge of genetics, but rather through that of their literary antecedents, the cultural-historical context of heredity and imagination and the scientific views of the eighteenth and nineteenth century, then the texts and their characters appear in a new light. As regards this respect, the physiognomic ideas of Lavater are particularly important.

Johann Kaspar Lavater's physiognomic fragments first appeared beginning in 1772 and soon became bestselling European publications with a major impact on different types of literature. Teeming with woodcut illustrations, the large-format versions and the cheap, pocketbook editions of his works followed one another in quick succession. The complex publication history estimates the existence of fifty-five (!) different editions until 1810 (on the publication history see Graham 1979). Remarkably early signs of the reception of Lavater's work 
Kucserka, Zsófia. "Parent-Child Resemblance in Literature Before the Age of Genetics: A Physiognomic Interpretation of the Novels of Zsigmond Kemény and Miklós Jósika." Hungarian Cultural Studies. e-Journal of the American Hungarian Educators Association, Volume 14 (2021): http://ahea.pitt.edu DOI: 10.5195/ahea.2021.416

in Hungary have been identified in Ferenc Kazinczy's correspondence conducted at the turn of the eighteenth and nineteenth century (Tóth 2015). Characterization and the description of facial features in Hungarian novels of the early nineteenth century frequently reveal the influence of Lavater. In Miklós Jósika's first novel, Abafi (1836), for example, the protagonist's stature and the countenance transform concurrently with his moral reformation (Kucserka 2017: 66-70). Further examples could be cited from the famous author, Mór Jókai (1825-1904)'s well-known novels, within the pages of which Lavaterian physiognomy noticeably motivates the presentation and interpretation of numerous characters. Viktor Szokoly's Hungarian translation of Lavater was published in 1864 as Arcisme és phrenológia ['Physiognomy and Phrenology for all Ranks of Readers']:

The greater the love and the fuller in their hearts, as Lavater says, the fuller their hearts are with pure and faithful affection, and the more naturally this silent love of father and mother merges, the more their children's facial expressions will be a complex from both of them. Such love, such attraction also presupposes a certain degree of imaginative power, which is able to retain the shape of the loved object... The mother's imagination has a great deal to do with the child's possible traits or its faults.

[Minél nagyobb szerelem és a szülök szivében minél-ugymond Lavater - sziveik minél teljesebbek tiszta és hü vonzalommal, s minél természetesebben olvad össze az atya és anya ezen néma szerelme: annál nagyobb mértékben lesznek gyermekei arckifejezései mindkettejük arckifejezéséböl összetettek. Az ily szerelem, az ily vonzalom bizonyos foku képzelö eröt is föltételez, mely a szeretett tárgy alakját magában megtartani képes.... Az anya képzelödése nagyon sokat hat a gyermek esetleges vonásaira, vagy annak hibáira.] (Szokoly 1864: 113-114)

Lavater discusses the subject of parent-child resemblance in chapter XXIII, where he focuses on which features are inherited from the mother and which from the father, and how the resemblance changes with the age of the child. Most relevant for the literary works discussed here, in the second half of the fragment Lavater touches upon the physiognomical commonplace that the child sometimes resembles someone else than the parents. In such cases, the mother's imagination determines the facial features of the child: "We also know that children most resemble the father only when the mother has a very lively imagination, and love for, or fear of the husband" (Lavater 1826: 142). This interpretation opens up a whole new set of questions for our texts, even if there are considerable differences in their treatment of the subject. In A könnyelmüek, Jósika's narrator governs the actions and their interpretation as well. With its silences and ellipses, however, Ködképek imposes no interpretation upon the reader regarding the events in the red room or the visage of the illegitimate child. Kemény rewrites the subject inherited from Jósika with considerable reduction and suppression, thereby leaving the interpretation of the story open for the reader. Is the resemblance there despite the fact that Ameline thought of Florestán in the red room, or precisely because Ameline recognized Jágó, and was terrified of him, or is there some other explanation for the similarity? When combined with her son's skin color, the fact that Ameline displays the same maternal affection towards both her son and her daughter forms evidence against Ameline by means of suggesting that there might have been no violence in the red room. This nuance, however, is missed when the Lavaterian aspect is ignored or unknown. 
Kucserka, Zsófia. "Parent-Child Resemblance in Literature Before the Age of Genetics: A Physiognomic Interpretation of the Novels of Zsigmond Kemény and Miklós Jósika." Hungarian Cultural Studies. e-Journal of the American Hungarian Educators Association, Volume 14 (2021): http://ahea.pitt.edu DOI: 10.5195/ahea.2021.416

Although the immediate literary context of the Kemény and Jósika's novels is Goethe's work, their essential intellectual background is Lavaterian physiognomy. Nonetheless, the question of heredity and imagination occurred much earlier in European intellectual history, as the following examples demonstrate. The Urtext of the subject is Heliodorus' novel, the Aethiopica (3rd c. A. D.). Apparently, the theme of black and white skin, heredity, and imagination is contemporaneous with European novel writing. The starting point for the intricate plot of Aethiopica is when Persinna, the black-skinned Ethiopian queen who gives birth to a white-skinned little girl. To escape the accusation of infidelity and prevent her husband's revenge upon Chariclea (the white daughter), the queen leaves the infant in the desert with some characteristic marks and abandons her to her fate. At the end of the novel, the recognition of the adult princess clears up all confusion, however, Queen Persinna must first exculpate herself. Sisimithres, the philosopher comes to her aid:

[A]s we are both Ethiopians, how could we for our offspring have a white child?" Sisimithres, with rather a sarcastic smile, replied... 'Deem of me as you please, I do not esteem it necessary to make any apology; we do not shape our lives so as to please others: we endeavour to follow the dictates of truth and virtue, and think it sufficient if we can approve our conduct to ourselves: yet, as to the doubt which you entertain concerning her complexion, the writing clears this up, explaining how Persina, from her contemplation of Andromeda, might have received an impression upon her mind agreeing with the subject of the picture. If you wish for farther proof, the original is at hand; examine the Andromeda, the likeness between the picture and the maiden will be found unmistakably exact.'

The king complied: and had the picture brought; when being placed near Chariclea, an instant cry of surprise, admiration, and joy, was raised throughout the assembly, at the striking likeness. (Heliodorus 1901: Book X)

Rediscovered in the sixteenth century, Aethiopica was available in many editions across Europe. It appeared in Hungarian in the form of a verse adaptation by István Gyöngyösi (1700), and then as a prose translation by András Dugonics (1798) (see Rajka 1917). Fortunately, Persinna's daughter only resembled a painting, a most innocent kind of similarity. However, even her children's remarkable resemblance to her husband could not defend the reputation of a princess in a fifteenth-century anecdote by Galeotto Marzio.

Once during a feast, there was a jest at the royal table, and there was talk of a prince whose wife was so willing to please anyone that she was considered a strumpet. However, a man with a notso-unscrupulous mind tried to protect the woman's reputation by saying that her children resembled her husband:

'If this woman were adulterous, as you think, she would give birth to sons like her lover, not her husband.'

For he believed that the main proof of the legitimacy of sons was that they resembled their parents. Then King Matthias said with a smile:

'You would not say that again, had you had turned through the pages in the books of wisdom.' Moreover, you would argue that a child's resemblance to his father testifies to an adulterous rather than an honest woman. For when women embrace their lover, they continually think of their husbands because they fear that their husbands will catch them red-handed. Hence it is that this fierce imaginary game carves the image of the parents into the foetuses. The example of the wise-minded sages, the most excellent doctors, and a plethora of examples prove that the imagination does it all. 
Kucserka, Zsófia. "Parent-Child Resemblance in Literature Before the Age of Genetics: A Physiognomic Interpretation of the Novels of Zsigmond Kemény and Miklós Jósika." Hungarian Cultural Studies. e-Journal of the American Hungarian Educators Association, Volume 14 (2021): http://ahea.pitt.edu DOI: 10.5195/ahea.2021.416

The woman's defender blushed, and we, laughing and full of joy, claimed that this was so, we recognized that, as Avicenna testifies, the soul has the power to change things. (Marzio 1977: 1112; on Galeotto Marzio's natural philosophical background see Békés 2014: 82-117. and Békés 2005).

The examples listed by Marzio suggest that, for a long time, the expected child's appearance was interpreted within the context of fidelity, infidelity and assumed adultery. The child's features therefore betray the parents, and especially the imagination of the mother. Yet, in a physiognomic context, the question of resemblance becomes more ambiguous. The face of the child - whomever he or she takes after - can be understood as the proof of assured fidelity and unquestionable infidelity as well. Fear and desire both act as powers of the imagination: either because it is desired or because it is feared, the evoked, imagined picture can be impressed on the expected child's face. A physiognomic interpretation of a child's face can lead to the moral exoneration of a woman but can also fuel accusations of adultery. According to scientific thinking before the age of genetics, the similarity or difference of the facial features of the child were explained not on a biological, but rather on an imaginative ground. Whomever the child resembles, be this an actual lover or the figure in a painting, the ultimate explanation for resemblance is always the creative imagination. As a force intermediating between the body and soul, imagination is a working of the soul which can cause physical transformation. No clear distinction therefore exists based upon which the resemblance of a child to his "true" biological father can be understood in scientific terms. In the same vein, the resemblance to someone (something) else calls for an esoteric, mysterious explanation. The difference between explanations hinges upon whether the maternal imagination that generated the facial features was influenced by desire or fear. Whether the face resembles the child's legitimate father or not, is simply a question of differentiating fidelity (love) from infidelity (fear).

Acknowledging the inherent interpretative ambiguity arising from contemporary physiognomical thinking is essential for the interpretation of nineteenth-century Hungarian novels. In the examined works by Zsigmond Kemény and Miklós Jósika, Lavaterian physiognomical theory provides a key for the characters' emotions and behavior. Instead of anachronistically locating the reason for the skin color of the child born from the union of the black man and the white women in present-day genetic theories of heredity, this factor should be interpreted as a result of the mother's imagination, her desires, or fears. Genetics-based examinations of fatherhood can only verify a mother's actions, not her thoughts. As the context of these novels reveal, however, the physiognomical interpretation of the child-parent relationship also tries to control, interpret, and restrain the imagination of the woman.

\section{Works Cited}

Akasoy, Anna. 2008. "Arabic Physiognomy as a Link Between Astrology and Medicine." Astro-Medicine: Astrology and Medicine, East and West. Eds. Anna Akasoy, Charles Burnett, Ronit Yoeli-Tlalim, Florence: Sismel-Edizioni del Galluzzo, 119-141.

Aristoteles. 1999. Physiognomica. Berlin: Akademia Verlag.

Badinter, Elisabeth. 1981. L'Amour en plus: histoire de l'amour maternel (XVIIe-XXe siècle). Paris: Flammarion. 
Kucserka, Zsófia. "Parent-Child Resemblance in Literature Before the Age of Genetics: A Physiognomic Interpretation of the Novels of Zsigmond Kemény and Miklós Jósika." Hungarian Cultural Studies. e-Journal of the American Hungarian Educators Association, Volume 14 (2021): http://ahea.pitt.edu DOI: 10.5195/ahea.2021.416

Békés, Enikő. 2005. "Physiognomy in the Descriptions and Portraits of King Matthias Corvinus." $\quad$ Acta Historiae Artium Academiae Scientiarum Hungaricae 46.1-4 (2005): 50-98.

-------. 2014. Asztrológia, orvoslás és fiziognómia Galeotto Marzio müveiben. Budapest: Balassi.

Dávidházi, Péter. 1998. The Romantic Cult of Shakespeare: Literary Reception in Anthropological Perspective. New York: St. Martin's Press.

Festetics, Imre. 1819. "Weitere Erklärungen des Herrn Grafen Emmerich von Festetics über Inzucht ['Further Explanations About Inbreeding by Count Emmerich von Festetics']'. Oekonomische Neuigkeiten und Verhandlungen 22 (1819. April): 169-172.

Gilman, Sander L. 1985. Difference and Pathology: Stereotypes of Sexuality, Race and Madness. Ithaca: Cornell UP.

Goethe, Johann Wolfgang. 1900. Elective Affinities. New York: Collier. https://archive.org/details/electiveaffiniti00goetuoft

Graham, John. 1979. Lavater's Essays on Phisiognomy: A Study in the History of Ideas. Berne: Peter Lang: (European University Studies 18).

Haly, Albohazen. 1485. De judiciis astrorum. Venice. Same in Spanish: Ibn Abi Rigal, Libro complido en los iudizios de las estrellas. ms. 3065, Bibliteca Nacional de Madrid.

Heliodorus. 1901. Aethiopica. Or, Adventures of Theagenes and Chariclea. The Greek Romances of Heliodorus, Longus, and Achilles Tatius. Trans. Rev. Rowland Smith. London: George Bell and Sons. Project Gutenberg, http://www.gutenberg.org/ebooks/55406

Jósika, Miklós. 1911. A könnyelmüek ['The Libertines']. Budapest: Franklin Társulat.

Kemény, Zsigmond. 2007. Levelezése ['Correspondence']. Budapest: Balassi-ELTE.

-------. 1996. Férj és nö-Ködképek a kedély láthatárán ['Husband and Wife Apparitions on the Mind's Horizon']. Budapest: Unikornis.

Kucserka, Zsófia. 2017. Könyvbe vésett jellemek. A szereplői karakter Kemény Zsigmondnál és a 19. századi magyar regényben ['Personality Molded into Book. The Persona Character in Zsigmond Kemény and in nineteenth-century Hungarian Novel’]. Budapest: Ráció.

Laczkó, S. András. 2019. "Kemény Zsigmond indiánjai: A Poharazás alatt Amerikaábrázolásáról. ['The Indians of Zsigmond Kemény. Representing America in The Drinking Party']" Verso 5, (2019/3): 56-78.

Lavater, Johan Caspar. 1826. Physiognomy, or the Corresponding Analogy between the Conformation of the Features and the Ruling Passions of the Mind. London.

Mendel, Johan Gregor. 1865. "Versuche über Pflanzen-Hybriden ['Experiments on Plant Hybrids']." Verhandlung des naturforschenden Vereins in Brünn 4 [1865], Brünn: Im Verlage des Vereines. Abhandlungen, 3-47.

Marzio, Galeotto. 1977. Mátyás királynak kiváló, bölcs, tréfás mondásairól és tetteiröl szóló könyv ['Excellent, Wise, Facetious Sayings and Deeds of King Matthias']. Budapest: Helikon.

Papp, Ferenc. 1923. Báró Kemény Zsigmond ['Baron Zsigmond Kemény’]. Budapest: A Magyar Tudományos Akadémia Kiadása.

Pearl, Sharrona. 2010. About Faces: Physiognomy in Nineteenth-Century Britain. Cambridge: Harvard UP.

Percival, Melissa. 2003. "Johann Caspar Lavater: Phisiognomy and Connoisseurship.” Journal for Eighteen-Century Studies 26/1 (2003): 77-90. 
Péterfy, Jenő. 1983. "Báró Kemény Zsigmond mint regényíró" ['Baron Zsigmond Kemény as a Novelist'] In P. J. Válogatott müvei ['Selected Works by Jenő Péterfy']. Budapest: Szépirodalmi, 550-585.

Rajka, László. 1917. Heliodoros Aithiopikájának feldolgozásai a magyar irodalomban ['Adaptations of Heliodorus' Aethiopica in Hungarian Literature']. Kolozsvár: Magyar Irodalomtörténeti Szeminárium.

Sabean, David Warren and Johnson, Christopher H. eds. 2011. Sibling Relations and the Transformations of European Kinship, 1300-1900. New York: Berghan Books.

Szokoly, Viktor. 1864. Arcisme és phrenologia, minden rendü olvasó számára ['Physiognomy and Phrenology for all Ranks of Readers']. Pest: Hartleben.

Tóth, Orsolya. 2015. “Az arc olvasása? Fiziognómiai szemlélet a 19. századi magyar irodalomban ['Reading a face? Physiognomical Perspective in Nineteenth-Century Hungarian Literature'].” Pécsi Tudományegyetem Bölcsész Akadémia 2. Pécs: PTE, 2744.

-------. 2019. "Description of Handwriting: Physiognomic Portraits in Nineteenth-Century Novels." Primerjalna književnost (Ljubljana) 42/2 (2019): 35-49.

Tytler, Greame. 1982. Physiognomy in the European Novel: Faces and Fortunes. Princeton: Princeton UP.

Wright, John P. and Potter, Paul. eds. 2000. Psyche and Soma: Physicians and Metaphysicians on the Mind-Body Problem from Antiquity to Enlightenment. Oxford: Oxford UP. 